\title{
Analysis of the Relationship the Development of Kualanamu Airport with the Development of Entrepreneurship of Youth in Batangkuis Sub-district, Deli Serdang Regency
}

\author{
Putri Andaria Nasution ${ }^{1}$, Sirojuzilam ${ }^{2}$, Marlon Sihombing ${ }^{3}$ \\ Universitas Sumatera Utara \\ \{putri.nasution18@gmail.com ${ }^{1}$, mrlnsihombing@gmail.com ${ }^{3}$ \}
}

\begin{abstract}
The existence of Kualanamu Airport has affected the increasing development environs the airport area including entrepreneurial activities of people or youth environs Batangkuis Sub-district, Deli Serdang Regency. This research is intended as one of the studies on the development of the region environs the airport-related to the development of youth entrepreneurship. The technique of collecting data using observation, interviews, questionnaires and document studies. The technique of analyzes data using descriptive analysis and non-parametric statistical analysis with the Rank Spearman technique. The result of the study concluded that (1) there is a positive relationship between the developments Kualanamu Airport with the development of youth entrepreneurship in Batangkuis Sub-district, Deli Serdang Regency; and (2) factors supporting regional development planning around airports are related to the development of youth entrepreneurship in Batangkuis Sub-district, among others: (1) equalization availability of trade and services facilities in each village such as market facilities, cooperatives, and banks, and (2) improvement of road accessibility and the provision or construction of rest area in toll gates.
\end{abstract}

Keywords: Kualanamu Airport, Youth Entrepreneurship Development, Batangkuis Subdistrict.

\section{Introduction}

The development of an area can be realized if it is supported by the availability of facilities and infrastructure such as roads, terminals, electricity, telephones, seaports, and airports. The existence of infrastructure has a very important role in realizing social interaction and the sustainability of the economic system. The better the state of infrastructure, the better the effect on social interaction and economic conditions of a region and will spur the progress and development of a region. This is possible because of transportation facilities and infrastructure function as forming, directing, and boosting the growth of an area. The existence of such a function can be seen from the extent of density that occurs in the land use of an area, as well as the intensity and frequency of socio-economic movements of the community. This activity will be further increased if an area is also supported by the availability of a complete transportation system and forms an integration between modes both road mode, rail mode, sea mode, and air mode. 
The construction of an airport (airport) will directly have an impact on the community around the airport. Passengers from aircraft will start and end their flight at the airport. Therefore, the existing service facilities at the airport will be very much needed for visitors and airplane passengers. These facilities can be in the form of waiting rooms, land vehicles, restaurants, hotels, restaurants, parking lots, shops, and various other matters related to the needs of goods and services. Besides, according to Nasution (2004), with the presence of airports in an area, a complete service unit will be formed with an expanded scope of activities. The existence of an airport will also foster centers of economic activity both trade and services. The growth of the activity center will employ the community around the airport. So that the most visible impact of the existence of a new airport in an area is the shifting of business units and changes in land use by the community around the airport.

Kualanamu Airport is an international airport located in Kualanamu, Deli Serdang Regency, North Sumatra Province. This airport is a solution for Polonia airport, which was Medan's previous international airport. The main reason for the move of Polonia airport to Kualanamu is due to limited development land and the explosion of passengers at the Polonia airport which should only be able to accommodate 2.5 million people per year to 8.1 million people per year. The transfer of Kualanamu Airport was planned in 1994 by the Central Government through the Ministry of Transportation using the state budget (APBN budget). The airport began operating on July 25, 2013, after experiencing construction delays in 1997 due to the monetary crisis. The airport construction work was restarted in 2006 by Vice President Jusuf Kalla and was inaugurated by President Bambang Susilo Yudhoyono on March 27, 2014.

Kualanamu has a strategic location and is one of the main gateways for aircraft passengers from Europe, the Middle East, and China. The vast land that stretches in the Kualanamu area opens wide opportunities to turn this airport into an atrocity/metropolis. Aerotropolis is a term for airport cities that have various facilities such as shopping centers, businesses, entertainment, and hospitality. This airport has been prepared as an international flight hub, rivaling Changi airport in Singapore and Kuala Lumpur International airport in Malaysia. Kualanamu Airport is the only airport in Deli Serdang Regency and is the largest airport in North Sumatra Province and even on the island of Sumatra. Since its inauguration in 2013, this airport has become one of the important infrastructures that support the smooth flow of transportation in meeting the needs of the community, especially the people of North Sumatra.

Airport construction activities are activities that aim to improve infrastructure in an area. Dikun (2003) explained that the existence of an airport in an area had a large influence or impact on economic growth. Besides, the development of a country or region, especially the area around the airport, has a relatively fast-growing region compared to other regions. This indicates that development activities cause changes to the surrounding area due to an activity in the area. The construction of Kualanamu Airport, located in Beringin and Pantai Labu Subdistricts, Deli Serdang Regency (about $39 \mathrm{Km}$ from Medan City), has influenced changes in the surrounding area in terms of physical, economic, social and cultural conditions. The change felt at this time is the decrease in agricultural land caused by the occurrence of landuse experts from agricultural land to developed land.

In addition to changes that occur physically, it turns out that the existence of Kualanamu Airport has also begun to influence the social and economic changes of the community in the form of increasing population and changing the livelihoods of the surrounding population. Changes in livelihoods are marked by the decrease in agricultural land which can cause 
increasingly shifting livelihoods of the population from the agricultural sector to move towards other sectors.

The existence of Kualanamu Airport has influenced the increasing developments occurring around the airport area, one of which is in the Batangkuis District. Since the planned transfer of Medan Polonia Airport to Kualanamu International Airport which borders Batangkuis District, the Subdistrict has continued to improve itself as Gapura District (the Main Gate and Door to the airport). The Batangkuis area is also slowly experiencing significant changes related to the growth of the business sector in the region, whose prospects are increasingly being sought after by investors. Several developers, both small and large, are continuing to expand their property business in the Batangkuis area, which is daily access to and from Kualanamu airport.

The Batangkuis sub-district, which has 11 villages and 72 hamlets, has indeed been affected positively by the presence of Kualanamu Airport. Since the operation of the Kualanamu airport in July 2013, the flow of traffic on several sections of the Batangkuis road has become more crowded than before the Kualanamu airport. The existence of Kualanamu Airport also makes some people in Batangkuis District start to develop their activities in the field of entrepreneurship or entrepreneurship. This can be seen from the number of community houses that began to change functions that were initially used as dwellings and are now also used as a place to trade (stalls or kiosks), restaurants, workshops or other businesses.

The results of Indah and Ma'rif's research (2014), regarding the influence of the existence of Kualanamu International Airport on socio-economic growth and physical changes in the surrounding area, concluded that the existence of Kualanamu Airport greatly affects the socioeconomic changes and physical changes in the surrounding area. Furthermore, the results of Sharfina's research (2014), on the impact of Kualanamu Airport construction on land values concluded that the existence of Kualanamu Airport influenced the social and economic changes in the surrounding community, especially in Beringin District which experienced changes in people's livelihoods.

Based on the description above, it is necessary to have research related to the influence of Kualanamu airport development on the development of the entrepreneurial population, especially in Batangkuis District, Deli Serdang Regency. The influence is manifested in the form of orientation, views or attitudes of the people (residents) related to the construction of Kualanamu Airport and its influence on the development of the entrepreneurial population. Orientation or attitude related to the development of entrepreneurship is needed because in the result it will be known the direction of business that is of interest to residents in Batangkuis District who are affected by airport construction, as well as the tendency of individual residents to innovate, be proactive and be willing to take risks to start or manage their businesses. This research can be used as a material consideration in the process of planning the development of the area around the airport relating to the development of entrepreneurship of its population so that population income will increase and grow the economy for the surrounding area.

\section{Materials and methods}

This research was conducted in Batangkuis District, Deli Serdang Regency, North Sumatra Province. When the study was conducted from May to July 2018. Data collection techniques using observation, interviews, questionnaires and documentation studies. Primary 
data collection techniques, data collection is done by observation and interview instruments. Secondary data collection techniques, carried out using literature study instruments, namely the collection of data or information relating to the problem to be examined through the review of books, journals, scientific works and expert opinions that are competent and have references to the problems they have. The data analysis technique used is descriptive analysis and non-parametric statistical analysis with Rank Spearman correlation technique (Ghozali, 2013):

$$
r=1-\frac{6 \sum d^{2}}{N\left(N^{2}-1\right)}
$$

\section{Result and discussion}

Batangkuis District is one of the Districts located in the Deli Serdang Regency with a distance of $\pm 11 \mathrm{Km}$ from the Capital of the Regency (Lubuk Pakam). Based on geographical location, Batangkuis District is located at 3059 '- 3066' North Latitude and 90869 '- 90882' East Longitude. The height of the area is above sea level between 4-30 meters and is categorized as a low-lying area with an area of $\pm 40.34 \mathrm{Km} 2$ or 1.62 percent of the total area of the Deli Serdang Regency. Batangkuis sub-district has 11 villages (village status) and 72 hamlets.

Table 1. The area by Village in Batangkuis District

\begin{tabular}{ccc}
\hline Number. & Village & Area $\left(\mathrm{Km}^{2}\right)$ \\
\hline 1 & Sena & 6,40 \\
2 & Tumpatan Nibung & 3,70 \\
3 & Baru & 4,32 \\
4 & Tanjung Sari & 7,34 \\
5 & Bakaran Batu & 0,45 \\
6 & Bintang Meriah & 0,65 \\
7 & Batangkuis Pekan & 0,75 \\
8 & Paya Gambar & 3,03 \\
9 & Sidodadi & 9,50 \\
10 & Sugiharjo & 1,53 \\
11 & Mesjid & 2,67 \\
& amount & 40,34 \\
\hline
\end{tabular}

Administratively, Batangkuis Sub-District is bordered by Pantai Labu Sub-District in the North, Beringin Sub-District in the South, Tanjung Morawa Sub-District in the East and bordering Percut Sei Tuan Sub-District in the West. 


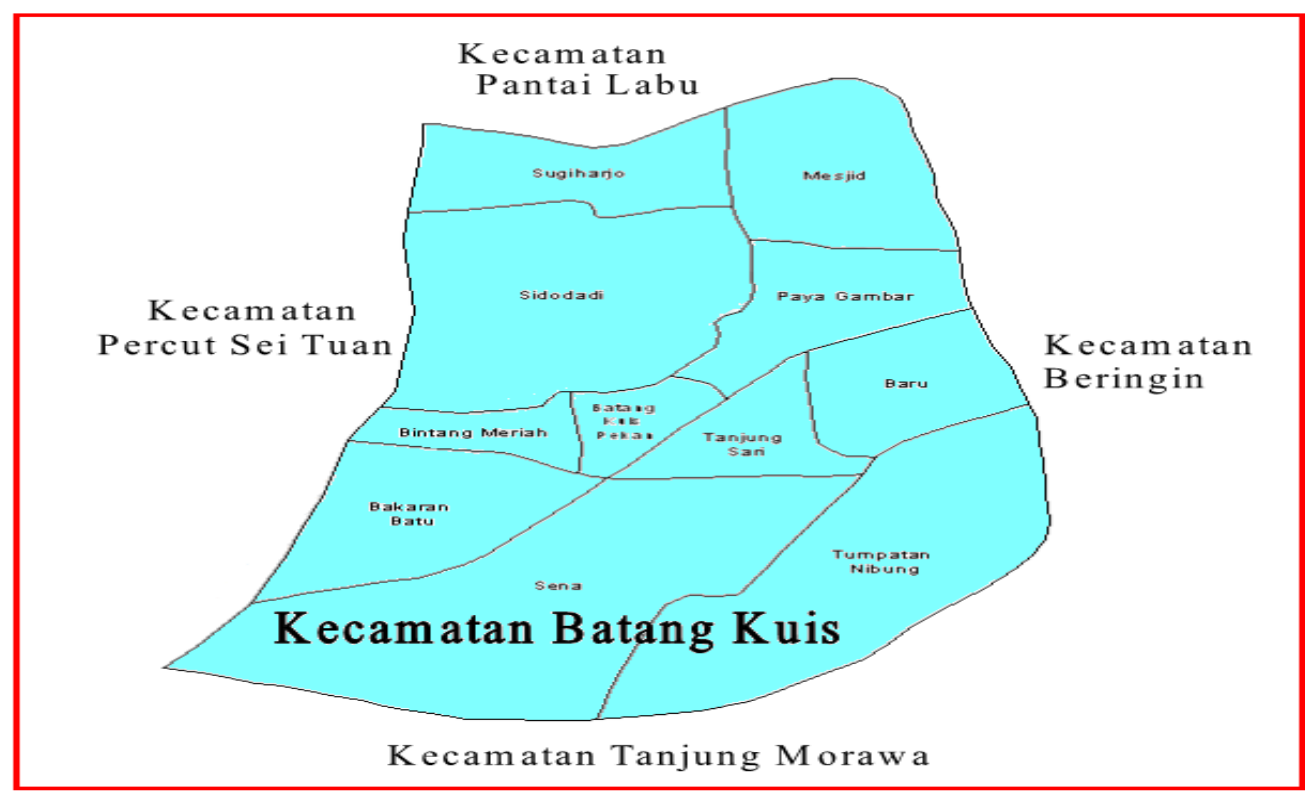

Fig. 1. Map of the Batangkuis subdistrict

The total population of Batangkuis District until 2016 has reached 65,090 people with an average population growth of $2.11 \%$ per year and a population density of 1,614 people per $\mathrm{Km}^{2}$.

Table 2. Number and Population Density of Batangkuis District (2010-2016)

\begin{tabular}{cccc}
\hline Year & $\begin{array}{c}\text { Total Population } \\
(\text { Soul })\end{array}$ & $\begin{array}{c}\text { An Area } \\
\left(\mathrm{Km}^{2}\right)\end{array}$ & Population Density $\left(\mathrm{Soul} / \mathrm{Km}^{2}\right)$ \\
\hline 2010 & 56.270 & 40,34 & 1.395 \\
2011 & 57.976 & 40,34 & 1.437 \\
2012 & 59.526 & 40,34 & 1.476 \\
2013 & 60.972 & 40,34 & 1.511 \\
2014 & 62.348 & 40,34 & 1.546 \\
2015 & 63.743 & 40,34 & 1.580 \\
2016 & 65.090 & 40,34 & 1.614 \\
\hline
\end{tabular}

Based on the data in the table above, it shows that the number and density of the population in the Batangkuis District over 7 years (2010-2016) has increased. Respondent characteristics in this study include the respondent's socioeconomic conditions, namely gender, age, last education, rural/urban village origin, and line of business. 
Table 3. Characteristics of Respondents by Gender

\begin{tabular}{cccc}
\hline Number. & Gender & Total & Percentage (\%) \\
\hline 1 & Man & 67 & 67,0 \\
2 & Women & 33 & 33,0 \\
& Total & 100 & 100 \\
\hline
\end{tabular}

Based on data from the questionnaire results as in the table above, obtained from 100 respondents as many as 67 respondents were male and 33 respondents were female. Characteristics of respondents based on age are divided into ages 16-20 years, 21-25 years, 26-30 years and 31-34 years. In summary, the respondent's age is summarized in the following Table 4 below.

Table 4. Characteristics of Respondents by Age

\begin{tabular}{cccc}
\hline Number. & Age & Total & Percentage $(\%)$ \\
\hline 1 & $16-20$ year & 5 & 5,0 \\
2 & $21-25$ year & 29 & 29,0 \\
3 & $26-30$ year & 53 & 53,0 \\
4 & $31-34$ year & 13 & 13,0 \\
& Total & 100 & 100 \\
\hline
\end{tabular}

Based on the questionnaire data as shown in Table 4.3 above, obtained from 100 respondents as many as 5 respondents aged between 16-20 years, as many as 29 respondents aged between 21-25 years, as many as 53 respondents aged between 26-30 years and as many as 13 respondents aged between 31-34 years old. Thus, the majority of respondents in this study were aged between 26-30 years, which was 53\%. The characteristics of respondents based on their last education are summarized in the following Table 5 below.

Table 5. Characteristics of Respondents Based on Last Education

\begin{tabular}{clcc}
\hline Number. & \multicolumn{1}{c}{ Last Education } & Total & Percentage (\%) \\
\hline 1 & Elementary School Graduate & 7 & 7,0 \\
2 & Junior High School Graduate & 11 & 11,0 \\
3 & High School Graduates & 42 & 42,0 \\
4 & Graduate Diploma & 4 & 4,0 \\
5 & Graduate Degree & 36 & 36,0 \\
& Total & 100 & 100 \\
\hline
\end{tabular}

Based on the questionnaire results data as in the table above, obtained from 100 respondents as many as 7 respondents who graduated from elementary school, 11 respondents graduated from junior high school, 42 respondents graduated from high school, 4 respondents graduated from Diploma and 29 respondents graduated from Bachelor (S1). Thus, the majority of respondents in this study were the last high school graduates $(42 \%)$. The characteristics of respondents based on village origin are summarized in the following Table 6 below. 
Table 6. Characteristics of Respondents by Village

\begin{tabular}{cccc}
\hline Number. & Village & Total & Percentage (\%) \\
\hline 1 & Sena & 11 & 11,0 \\
2 & Tumpatan Nibung & 14 & 14,0 \\
3 & Baru & 12 & 12,0 \\
4 & Tanjung Sari & 12 & 12,0 \\
5 & Bakaran Batu & 4 & 4,0 \\
6 & Bintang Meriah & 2 & 2,0 \\
7 & Batangkuis Pekan & 19 & 19,0 \\
8 & Paya Gambar & 15 & 15,0 \\
9 & Sidodadi & 4 & 4,0 \\
10 & Sugiharjo & 2 & 2,0 \\
11 & Mesjid & 5 & 5,0 \\
& Total & 100 & 100 \\
\hline
\end{tabular}

Based on the questionnaire data as shown in the table above, obtained from 100 respondents as many as 11 respondents from Sena village, 14 respondents from Tumpatan Nibung village, 12 respondents from Baru village, 12 respondents from Tanjung Sari village, 4 respondents came from Bakaran Batu village, 2 respondents came from Bintang Meriah village, 19 respondents came from Batangkuis Pekan village, 15 respondents came from Paya Gambar village, 4 respondents came from Sidodadi village, 2 respondents came from Sugiharjo village, and as many as 5 respondents came from the Mesjid village. Thus, the majority of respondents in this study came from Batangkuis Pekan village (19\%). Characteristics of respondents based on the business sectors occupied are briefly summarized in the following Table 7 below

Table 7. Characteristics of Respondents by Business Sector

\begin{tabular}{cccc}
\hline Number. & Business Fields & Total & Percentage (\%) \\
\hline 1 & Pengisian Pulsa/Data Internet & 26 & 26,0 \\
2 & Toko Pakaian/Sepatu/Sandal & 15 & 15,0 \\
3 & Warung Bakso/Cilok/Gorengan & 12 & 12,0 \\
4 & Bengkel Mobil/Sepeda Motor & 10 & 10,0 \\
5 & Warung Minuman/Es Kelapa/Cendol & 9 & 9,0 \\
6 & Pencucian Kenderaan/Doorsmeer & 8 & 8,0 \\
7 & Toko/Grosir Sembako & 7 & 7,0 \\
8 & Isi Ulang Air Mineral & 4 & 4,0 \\
9 & Rumah Makan & 3 & 3,0 \\
10 & Panglong & 3 & 3,0 \\
11 & Toko Alat Pancing & 2 & 2,0 \\
12 & Toko Perabot & 1 & 1,0 \\
& Total & 100 & 100 \\
\hline
\end{tabular}

Based on data from the questionnaire results as in table above, obtained from 100 respondents as many as 26 respondents whose business is in the field of charging pulses per internet data, as many as 15 respondents shop clothing/shoes/sandals business, as many as 12 respondents of meatballs/cilok/fried food stalls, as many as 10 respondents in the garage / motorbike workshop business, as many as 9 respondents in the beverage / ice shop / cendol stall business, as many as 8 respondents in the washing business/doorsmeer business, as many as 7 respondents in the shop / grocery business, as many as 4 respondents in the mineral water 
refill business, as many as 3 respondents were restaurant businesses, 3 respondents were panglong businesses, as many as 2 respondents were fishing shop businesses, and as many as 1 respondents were furniture shop businesses. Thus, based on the data available the majority of respondents in this study have a business in the field of topping up / internet data (26\%).

\section{Result and discussion}

Data on the Kualanamu airport development was obtained by giving a set of questionnaires (10 questions) to 100 respondents. Descriptive statistics of respondents' responses regarding the development of Kualanamu Airport are summarized in the following Table 8 below.

Table 8. Description of respondents about Kualanamu Airport Development

\begin{tabular}{cccccccc}
\hline & N & Minimum & Maximum & Sum & Mean & $\begin{array}{c}\text { Std. } \\
\text { Deviation }\end{array}$ & Variance \\
\hline $\begin{array}{c}\text { Kualanamu } \\
\text { Airport } \\
\begin{array}{c}\text { Development } \\
\text { Valid N (listwise) }\end{array}\end{array}$ & 100 & 25 & 39 & 3160 & 31.60 & 3.869 & 14.970 \\
\hline
\end{tabular}

Based on the data in Table 8 above, it can be explained that the responses of respondents regarding the development of Kualanamu Airport, from the 100 respondents obtained the lowest score of 25 and the highest score of 39 with an average score of 31.60 and a standard deviation of 3.869. The level of respondent responses regarding the development of Bandar Kualanamu is presented in Table 9 below.

Table 9. Trend level of respondents' about Kualanamu Airport Development

\begin{tabular}{ccccl}
\hline Number. & Value Interval & Total & Percentage (\%) & Category \\
\hline 1 & $34-40$ & 34 & 34,0 & Very Good \\
2 & $26-33$ & 62 & 62,0 & Good \\
3 & $18-25$ & 4 & 4,0 & Pretty Good \\
4 & $10-17$ & 0 & 0,0 & Not Good \\
& Total & 100 & 100 & \\
\hline
\end{tabular}

Based on the data in Table 4.8 above, it can be explained that the level of tendency of respondents' responses regarding the development of Kualanamu Airport, out of 100 respondents, 34 respondents were classified as very good category, 62 respondents were classified as good category, and 4 respondents were classified as a quite good category. Thus, based on research data, the majority of respondents' responses regarding the development of Kualanamu Airport tend to be classified as good (62\%). This result indicates that the respondents responded well to the development of Kualanamu Airport. The respondents also agreed that the development of Kualanamu Airport had a positive influence on the economy of the family, could stimulate socio-economic growth and a positive impact on the availability of economic facilities in the surrounding area as well as more access to transportation. The respondents also strongly support the development of Kualanamu Airport. Data on the 
development of youth entrepreneurship in the Batangkuis District was also obtained by giving a set of questionnaires (20 questions) to 100 respondents. Descriptive statistics of respondents' responses to the development of youth entrepreneurship in the Batangkuis District are summarized in the following Table 10 below.

Table 10. Statistical descriptions of respondents' Youth Entrepreneurship Development in Batangkuis District.

\begin{tabular}{|c|c|c|c|c|c|c|c|}
\hline & $\mathrm{N}$ & Minimum & Maximum & Sum & Mean & $\begin{array}{c}\text { Std. } \\
\text { Deviation }\end{array}$ & $\begin{array}{c}\text { Varianc } \\
\mathrm{e}\end{array}$ \\
\hline $\begin{array}{c}\text { Youth } \\
\text { Entrepreneurship } \\
\text { Development }\end{array}$ & 100 & 51 & 77 & 6368 & 63.68 & 5.222 & 27.270 \\
\hline Valid N (listwise) & 100 & & & & & & \\
\hline
\end{tabular}

Based on the data in Table 10 above, it can be explained that the responses of respondents about youth entrepreneurship in the Batangkuis District, of the 100 respondents obtained the lowest score of 51 and the highest score of 77 with an average score of 63.68 and a standard deviation of 5.222. Furthermore, the level of respondent's tendency towards youth entrepreneurship in the Batangkuis District is presented in Table 11 below.

Table 11. Trends in Respondents' on Youth Entrepreneurship Development in Batangkuis District

\begin{tabular}{ccccc}
\hline Number. & Interval Nilai & Total & Percentage (\%) & Category \\
\hline 1 & $66-80$ & 38 & 38,0 & Very good \\
2 & $51-65$ & 62 & 62,0 & Good \\
3 & $36-50$ & 0 & 0,0 & Enough \\
4 & $20-35$ & 0 & 0,0 & Not enough \\
& Total & 100 & 100 & \\
\hline
\end{tabular}

Based on the data in Table 11 above, it can be explained that the level of the tendency of respondents' responses about youth entrepreneurship in Batangkuis Subdistrict from 100 respondents, 38 respondents were classified as very good category and 62 respondents were classified as good categories. Thus, based on research data, the majority of respondents' responses regarding the development of youth entrepreneurship in the Batangkuis Subdistrict tend to be classified as good $(66 \%)$. To find out the relationship between the development of Kualanamu Airport and the development of youth entrepreneurship in the Batangkuis Subdistrict were analyzed by non-parametric statistical analysis using the Rank Spearman correlation technique with the help of the SPSS program. The results of the Spearman Rank analysis are presented in Table 12 below. 
Table 12. Rank Spearman Analysis Relationship between Kualanamu Airport Development and Youth Entrepreneurship Development in Batangkuis District

\begin{tabular}{ccccc}
\hline & & & $\begin{array}{c}\text { Youth } \\
\text { Kualanamu Airport } \\
\text { Development }\end{array}$ & $\begin{array}{c}\text { Entrepreneurship } \\
\text { Development }\end{array}$ \\
\hline Spearman's rho & $\begin{array}{c}\text { Kualanamu Airport } \\
\text { Development }\end{array}$ & $\begin{array}{c}\text { Correlation Coefficient } \\
\text { Sig. (2-tailed) }\end{array}$ & 1.000 & $.469^{* *}$ \\
& Youth & $\mathrm{N}$ & 100 & .000 \\
& Entrepreneurship & Correlation Coefficient & $.469^{* *}$ & 100 \\
& Development & Sig. (2-tailed) & .000 & 1.000 \\
& $\mathrm{~N}$ & 100 &. \\
\hline
\end{tabular}

**Correlation is significant at the 0.01 level (2-tailed).

Based on the data in the table above, it can be explained that the results of Spearman rank correlation analysis obtained correlation coefficient (correlation coefficient) of 0.469 with a probability value or Sig of 0.000 . Because the probability value or Sig is $0,000<0.05$, then the hypothesis is statistically accepted so that it can be concluded that there is a positive and significant relationship between the development of Kualanamu Airport with the development of youth entrepreneurship in Batangkuis District.

Batangkuis Subdistrict is one of the Subdistricts in the region of Deli Serdang Regency, North Sumatra Province, which has also experienced changes since the construction of Kualanamu Airport. Since the planned transfer of Medan Polonia Airport to Kualanamu International Airport which borders Batangkuis District, the Subdistrict has continued to improve itself as Gapura District (the Main Gate and Door to the airport). The Batangkuis area is also slowly experiencing significant changes related to the growth of the business sector in the region, whose prospects are increasingly being sought after by investors. Several developers, both small and large, are continuing to expand their property business in the Batangkuis area, which is daily access to and from Kualanamu airport.

The growth of this growth has been seen in several locations in the direction of the airport entrance. Exactly in Batangkuis District, which has access to and from the airport, now seems to change compared to before the Kualanamu airport. Batangkuis Subdistrict, which has 11 villages and 72 hamlets, was indeed positively affected by the presence of Kualanamu Airport. Since the operation of the Kualanamu airport in July 2013, the flow of traffic on several sections of the Batangkuis road has become more crowded than before the Kualanamu airport. The existence of Kualanamu Airport also makes some people in Batangkuis District start to develop their activities in the field of entrepreneurship or entrepreneurship. This can be seen from the number of community houses that began to change functions that were initially used as dwellings and are now also used as a place to trade (stalls), restaurants, workshops or other businesses. The existence of Medan-Kualanamu-Tebing Tinggi toll road access also affects community activities in the field of entrepreneurship.

Based on the findings of the research that has been done, the researcher underlines several factors supporting the planning of the development of the area around Kualanamu Airport relating to the development of youth entrepreneurship in Batangkuis District, including (1) equal distribution of the availability of trade or service facilities or facilities in each village in Batangkuis District such as market/weekend facilities, cooperatives and banks; and (2) 
improvement or improvement of road accessibility so that it will increase community entrepreneurial activities, especially youth, and increase social economic activities in the Batangkuis District.

\section{Conclusions}

Based on the results of the analysis and discussion that has been carried out, the following conclusions are obtained (1) there is a positive relationship between the development of Kualanamu Airport and the development of youth entrepreneurship in Batangkuis District, Deli Serdang Regency. This indicates that the better the response of young people about the development of Kualanamu Airport, the better the development of youth entrepreneurship in the District of Batangkuis, Deli Serdang Regency, and (2) supporting factors for planning the development of the area around the airport is related to the development of youth entrepreneurship in Batangkuis District, including: (1) equitable distribution of trade or service facilities or services in every village in Batangkuis District such as market / weekend facilities, cooperatives and bank; and (2) improvement or improvement of road accessibility as well as rest areas in toll road entrances and exits.

\section{References}

[1] Badan Pusat Statistik. Kecamatan Batangkuis dalam Angka 2017. BPS Kabupaten Deli Serdang.

[2] Indah, N.F., dan Ma'rif, S. 2014. Pengaruh Keberadaan Bandara Internasional Kualanamu terhadap Perubahan Sosial Ekonomi dan Perubahan Fisik Kawasan Sekitarnya. Teknik PWK. Vol. 3, No. 1, p: 82-95.

[3] Sudjana. 2004. Dasar-Dasar Proses Belajar Mengajar. Bandung: Sinar Baru Algensindo.

[4] Tarigan, R. 2005. Ekonomi Regional. Bumi Aksara: Jakarta 